\title{
Perforation of Axillary Vein by a Branch of the Axillary Artery - an Anatomical Study
}

\author{
Perforación de la Vena Axilar por una Rama de la Arteria Axilar - un Estudio Anatómico
}

*Anita Mahajan; ${ }^{* *}$ K. K. Rana $\&{ }^{* * *}$ S. Saha

MAHAJAN, A.; RANA, K. K. \& SAHA, S. Perforation of axillary vein by a branch of the axillary artery- an anatomical study. Int. J. Morphol., 30(2):579-582, 2012.

SUMMARY: Anatomical variations in the region of axilla and pectoral region are very common. These variations need attention to avoid complications arising during surgeries and diagnostic and interventional invasive procedures in this region such as surgeries for breast carcinoma, venous access during central venous line, pacemaker and cardiac defibrillator implantation etc. During routine cadaveric dissection we had noticed a rare variation of axillary vein and artery. In this case axillary vein, just deep to the inferior border of pectoralis minor was pierced by the lateral thoracic artery, a branch of axillary artery. Perforation of the axillary vein by a branch of the axillary artery is extremely rare variation encountered till now. We report a variation wherein the lateral thoracic artery a branch of the second part of axillary artery was unusually long and perforated the axillary vein, just posterior to the inferior border of pectoralis minor muscle before supplying the structures in the anterolateral chest wall. Histological findings revealed duplication of lumen at the site of perforation through which the lateral thoracic artery was passing and the surrounding area was sealed by the connective tissue. Sound knowledge of anatomy of axillary and pectoral region may help in reducing complications while doing surgical and diagnostic procedure in these regions.

KEY WORDS: Axilla; Arterial anomaly; Venous anomaly.

\section{INTRODUCTION}

Sound knowledge of anatomy of axillary region is important for successful surgeries and invasive diagnostic procedures because injuries to the axillary vessels are associated with high morbidity rates (Demetriades \& Asensio, 2001).

Veins of upper limb are commonly used for drawing blood samples, infusion, blood transfusion, catheterization and for various diagnostic and therapeutic invasive procedures (Decker \& du Plessis, 1986; Andel et al., 1999; Moore \& Dalley, 1999). Various invasive therapeutic and diagnostic procedures are done in the axillary region as in axillary dissection for the staging and treatment of lymph node metastasis in breast carcinoma (Wright \& Long, 2011). Surgical exposure of the axillary vessels can be difficult and needs thorough knowledge of local anatomy and its variations (Berry \& Wallis, 1977; Demetriades \& Asensio). Variation in the course and relations of axillary vessels has been observed by the various investigators. The axillary vein extends from the lower border of the teres major muscle to the outer border of the first rib, where it is surrounded by nerves from the distal brachial plexus (Hollinshead, 1956). The axillary vein is the direct continuation of basilic vein in the axilla and along its course closely related to the axillary artery and the cords and branches of the brachial plexus (Standring, 2009). Several investigators have observed variations in the course and relations of the axillary vein in humans and other primates (Bergman et al., 1988). Perforation of the axillary vein by a branch of the axillary artery is extremely rare variation. We report a variation wherein the lateral thoracic artery, a branch of second part axillary artery was unusually large and perforated the axillary vein in its middle part before supplying structures in the anterolateral chest wall. We have described and discussed the topography, morphology and clinical significance of venous and arterial variations. It is important for surgeons and radiologists to be aware of these types of variations to minimize the complications during surgery (Guloglu et al., 1999). 


\section{CASE REPORT}

In a series of routine dissection of 40 embalmed human cadavers for under graduate teaching programme in a span of five years, a variation in the axillary artery and vein was observed in a right upper limb of a 50 year old male cadaver whereas left axillary artery and vein were normal.

Observations: Lateral thoracic artery (LTh A- in Figs. 1 and 2) arose from the 2nd part of axillary artery (AxA- in Figs. 1 and 2) approximately $2 \mathrm{~cm}$ distal to the outer border of $1 \mathrm{st}$ rib coursed downwards and medially and perforated the axillary vein ( $\mathrm{AxV}$ - in Figs. 1 and 2) from posterior to anterior straight through the opening in the wall of the vein formed by the splitting of axillary vein. After perforation the artery gave branches, of which one branch (A in- Figs. 1 and 2) ran along the superior border of pectoralis minor muscle (P. minor in Figs. 1 and 2), middle branch (B inFigs. 1 and 2) deep to the pectoralis minor muscle and the third branch (C- in Figs. 1and 2) along the inferior border of pectoralis minor muscle and they supplied the structures present in the anterolateral aspect of chest wall. Superior thoracic artery (SThA in Figs. 1 and 2) and Thoraco-acromial vessels (ThAVs in Figs. 1 and 2) had normal course and distribution in this case.

Histological examination revealed duplication of lumen at the site of perforation and wall of the vein around the artery had all the three tunics.

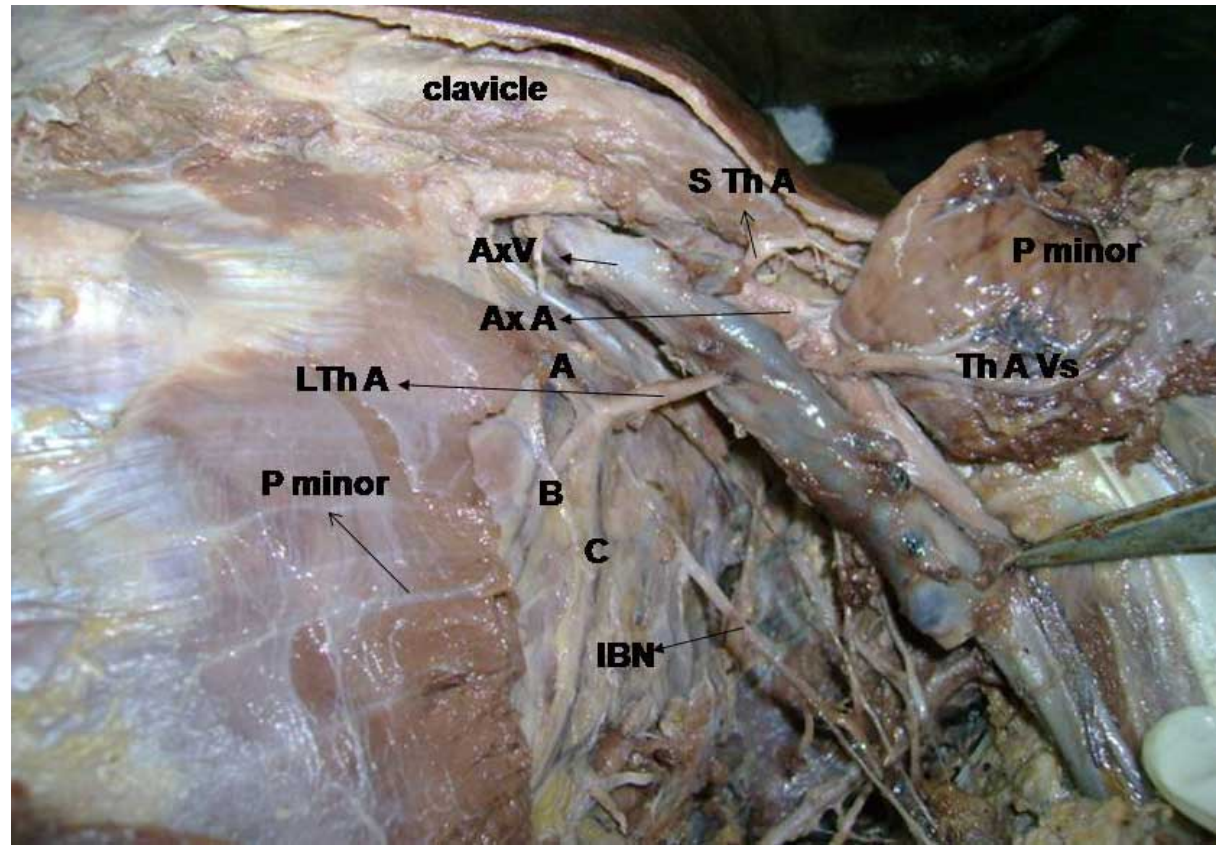

Fig.1. Photograph of dissected area. AxV- Axillary vein, AxA- Axillary artery, LThALateral thoracic artery, P. Minor-Pectoralis minor muscle, IBN- Intercostobrachial nerve, SThA-superior thoracic artery, ThA Vs- Thoraco-acromial vessels.

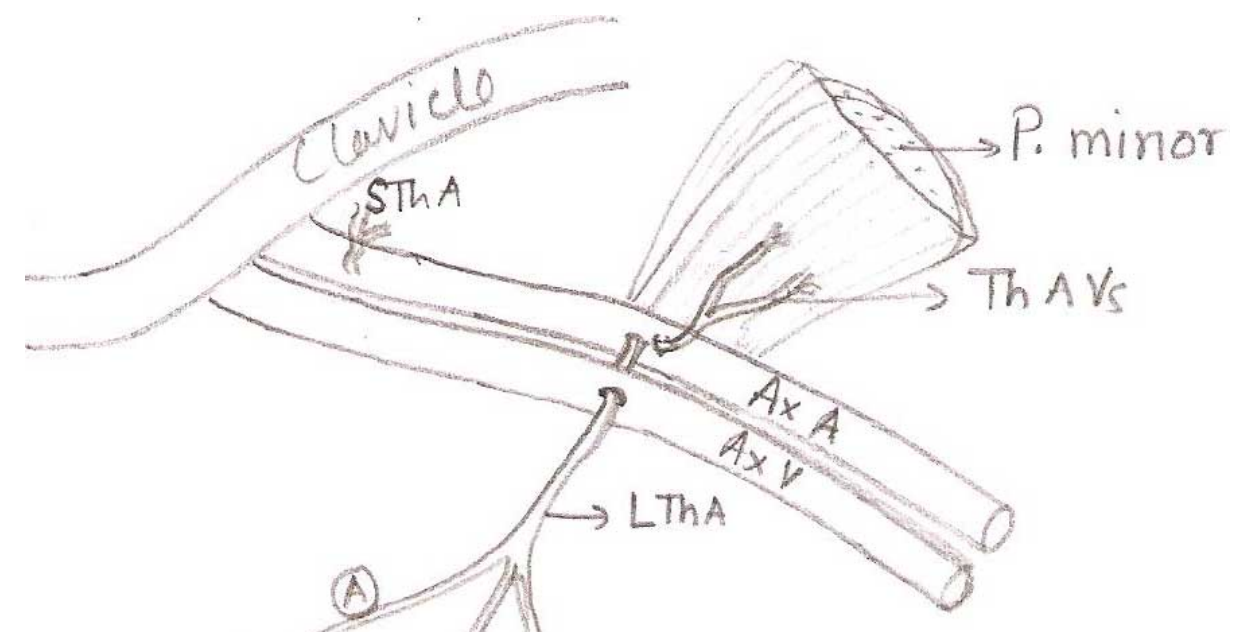

Fig. 2. Line diagram of variation found in dissected specimen. AxV- Axillary vein. AxA- Axillary artery. LThA- Lateral thoracic artery.

P. Minor-Pectoralis minor muscle. IBN- Intercostobrachial nerve. SThA-superior thoracic artery. ThAVs- Thoraco-acromial vessels. 


\section{DISCUSSION}

Clinical significance of this anomaly can be understood by considering the development of veins of the upper limb.

The axillary vein develops from the condensation of mesenchyme in upper limb bud. Proliferation of vascular cells, further differentiation and branching patterns depends on the role of extrinsic inhibitory factors in embryonic life. Anastomosis develops between the superficial and deep vessels or vessels can regress due to influence of haemodynamic factors leading to development of adult pattern of superficial and deep vessels. Superficial capillary plexus persist for the development of superficial veins of the upper limb and during the development process; if the branch of the axillary artery gets trapped within the venous plexus it may give rise to the variation as we have found in the present case.

There are cases which described the perforation of axillary vein by medial cutaneous nerve of forearm or by its collateral branch and gave the details of variant vein and its relationship with the medial cutaneous nerve of forearm (Roy \& Sharma, 2004). Similar venous loops in the subclavian and jugular vein were found around the phrenic nerve and the accessory nerve respectively (Gardiner et al., 2002).

Anomaly described here has significant implications in medical practice because the axillary vein is very commonly used as alternate route for venous access during Pacemaker \& ICD implantation, evaluation of central venous thrombosis in thoracic outlet compression and treatment of breast carcinoma (Bellot, 1999; Moore \& Dalley; Decker \& du Plessis), Venous anomalies may cause difficulty and complications in implanting DDD pacemaker (Lelakowski et al., 2007), placement of central venous line (in severe burn) (Andel et al.) and Upper extremity venography. Preferred sites for central venous access in infants and children are the external and internal jugular veins, the subclavian and axillary veins, and the femoral vein (Haas, 2004).

Difficulties in putting central venous line or malpositoned tip of catheters are commonly encountered in venous access because of the obstructed lumen of the vein.

Double channel at the site of perforation may increase the chances of spontaneous thrombosis and emboli formation even in trivial mechanical injuries and during surgical procedures (Chang \& Oh, 1988).

Variant axillary artery and vein may get damaged during the block dissection of axillary lymph nodes during mastectomy operation for carcinoma breast.

Variations in the axillary artery and vein may be detected only during the surgical procedures or after developing local complications.

Variation described in this study may remain undetected until discovered during surgical intervention or after development of complications. So we feel that sound knowledge of normal anatomy and its variation are important and necessary for the surgeons to prevent injury to the axillary vessel and the other structures in the axilla and thus help minimizing the complications during invasive surgical and diagnostic procedures.

ACKNOWLEDGEMENTS. The authors acknowledge the contribution of undergraduate students, teachers and staff of Maulana Azad Medical College, New Delhi, in laboratory dissection, histological preparation and technical assistance.

MAHAJAN, A.; RANA, K. K. \& SAHA, S. Perforación de la vena axilar por una rama de la arteria axilar - un estudio anatómico. Int. J. Morphol., 30(2):579-582, 2012.

RESUMEN: Las variaciones anatómicas en las regiones axilar y pectoral son muy comunes. Estas variaciones necesitan atención para evitar las complicaciones que surgen durante las cirugías y los procedimientos invasivos de diagnóstico e intervención en esta región, tales como cirugía de cáncer mamario, acceso venoso para una vía venosa central, implantación de marcapasos y desfibrilador, etc. Durante una disección de rutina se evidenció una variación poco frecuente de la vena axilar y arteria axilar. Se presenta una variación en que la arteria torácica lateral, rama de la segunda parte de la arteria axilar, inusualmente larga, perforaba la vena axilar, justo por detrás del margen inferior del músculo pectoral menor, antes de irrigar a las estructuras de la pared torácica anterolateral. La histológía reveló la duplicación del lumen en el sitio de perforación a través del cual pasa la arteria torácica lateral, que periféricamente fue sellada por tejido conectivo. La perforación de la vena axilar por una rama de la arteria axilar es una variación que raramente se observa, por eso un buen nivel de conocimientos de la anatomía de las regiones axilar y pectoral puede ayudar a reducir las complicaciones cuando se realizan procedimientos quirúrgicos y de diagnóstico en estas regiones.

PALABRAS CLAVE: Axila; Anomalía arterial; Anomalía Venosa. 


\section{REFERENCES}

Andel, H.; Rab, M.; Felfernig, M.; Andel, D.; Koller, R.; Kamolz, L. P. \& Zimpfer, M. The axillary vein central venous catheter in severely burned patients. Burns, 25(8):753-6, 1999.

Belott, P. H. Blind axillar venous access. Pacing Clin. Electrophysiol., 22(7):1085-9, 1999.

Bergman, R. A.; Thompson, S. A.; Afifi, A. K. \& Saadeh, F. A. Compendium of human anatomic variation. Baltimore, Urban \& Schwarzenberg, 1988. pp.72-5.

Berry, P. R. \& Wallis, W. E. Venepuncture nerve injuries. Lancet, 1(8024):1236-7, 1977.

Chang, C. W. \& Oh, S. J. Medial antebrachial cutaneous neuropathy: case report. Electromyogr. Clin. Neurophysiol., 28(1):3-5, 1988.

Decker, G. A. G. \& du Plessis, D. J. Lee McGregor's synopsis of surgical anatomy. 12th ed. Bristol, John Wright and Sons Ltd., 1986. pp.250-1.

Demetriades, D. \& Asensio, J. A. Subclavian and axillary vascular injuries. Surg. Clin. North Am., 81(6):1357-73, xiii, 2001.

Gardiner, K. J.; Irvine, B. W. \& Murray, A. Anomalous relationship of the spinal accessory nerve to the internal jugular vein. Clin. Anat., 15(1):62-3, 2002.

Guloglu, R.; Bilsel, Y.; Alis, H.; Ertekin, C. \& Kurtoglu, M. Traumatic subclavian and axillary vessel injuries. Int. J. Angiogr., 8:105-8, 1999.

Haas, N. A. Clinical review: vascular access for fluid infusion in children. Crit. Care, 8(6):478-84, 2004.

Hollinshead, W. H. Anatomy for surgeons. Vol. 1. New York, HoeberHarper, 1958.

Lelakowski, J.; Majewski, J.; Ma?ecka, B.; Bednarek, J.; Stypu?a, P. $\&$ Szeglowski, M. Retrospective analysis of reasons for failure of DDD pacemaker implantation in patients operated on between 1993 and 2005. Cardiol J., 14(2):155-9, 2007.

Moore, K. L. \& Dalley, A. F. Clinically oriented Anatomy. 4th ed. Philadelphia, Lippincott Williams \& Wilkins, 1999.

Roy, T. S. \& Sharma, S. Axillary vein perforation by the medial cutaneous nerve of the forearm. Clin. Anat., 17(4):300-2, 2004.

Standring, S. Gray's Anatomy. The Anatomical Basis of Clinical Practice. 39th ed. Philadelphia, Elsevier Churchill Livingstone, 2005.

Wright, M. J. \& Long, J. N. Surgical Treatment of Breast Cancer, 2011. Available in: http://emedicine.medscape.com/article/ 1276001-overview

\author{
Correspondence to: \\ Dr. Anita Mahajan \\ P-23, 2nd floor Malviya Nagar5 \\ New Delhi-110017 \\ INDIA
}

Phone: 0091-11-26682654, 0919968604209

Email: anitamahajan24@gmail.com

Received: 16-01-2012

Accepted: 13-03-2012 